\title{
RESENHA
}

\section{PROBLEMAS E PROPOSTAS DE SOLUÇōES PARA O VINCULO ENTRE LINGUAGEM E LEITURA}

\author{
MARTINS, Maria Helena, (org.) Questōes de linguagem. Săo Paulo: Contexto, 1991. (Coleçáo Repensando o ensi-
}

no)

\section{SONIA MARIA MARQUES DE OLIVEIRAI}

Esta obra é uma compilaçāo de vários textos de professores e pesquisadores da USP, UNICAMP e outras instituiçōes, preocupadas com o atual processo educacional brasileiro que envolve questōes de linguagem. Os trabalhos editados incursionam por experiencias e reflexōes que tencionam solucionar falhas e dificuldades do ensino da lingua.

Dentre os problemas apresentados Haquira Osakabe reflete sobre a "educaçāo linguística" inclusa em um processo educacional "burocratizante" e "estigmatizante". Somado a este processo, Adilson Odair Citelli exemplifica como a falta de planejamento, no ensino da linguagem verbal, ignora e pouco usufrui da linguagem dos meios de comunicaçăo de massa como instrumento para estudos semânticos da língua.

Maria Helena Martins nos revela suas inquietaçōes demonstrando a dicotomia que se faz entre a linguagem verbal e visual, visto que a escola, ainda, "restringe a noção de leitura a um processo racional de atribuição de significado à palavra escrita...". (p. 97). Nesta linha de pensamento, a autora demonstra as possibilidades de intersecção entre o visual e o verbal, alertando para a prática de leitura de várias linguagens e em vários niveis. Sugere que linguagem e leitura devam ser processos dinâmicos, sugestivos, entrelaçando a "imaginaçāo visiva e verbal".

$\mathrm{Na}$ busca de elementos responsáveis pela crise da leitura, enorme culpabilidade se atribue à televisáo. Maria Thereza F. Rocco atenta ao poder e onipotência deste meio de comunicaçăo de massa; faz um entrelaçamento da TV e literatura, demonstrando que a leitura de um texto televisual "nos impōe de fora e de cima a necessidade de uma recepçăo veloz..", ao passo que o texto literário "nos lança em um corpo-a-corpo direto com aquele "real" contato e recriado, - permitindo o demorar-se" (p. 85). Mencionando Teixeira Coelho, a autora conclue que a televisăo deve ser considerada um veiculo de lazer, e năo de cultura de massa, visto que suas funçōes de educaçăo e informaçăo deixaram de ser exercidas. Desta forma, as deficiencias no ensino da linguagem se iniciam com o uso de cartilhas como instrumento de alfabetizaçăo.
Mary Julia M. Dietzch, pesquisando as cartilhas utilizadas por cinco décadas, descreve que as mesmas nåo retratam em seu conteúdo a evolução do contexto histórico-cultural e seus textos são caracterizados pela impessoalidade, onde "a fala é negada ao leitor" (p. 38). Neste continuo de pensamento Marisa Lajolo exemplifica, com fragmentos de textos, a "impessoalidade" e "objetividade" da linguagem da ciência e o cruzamento desta com a linguagem da poesia. No entanto, um dos fatores estimuladores de tantas deficiências pode estar na maneira pela qual o professor lé o texto do aluno. Sobre este aspecto, João Wanderley Geraldi tece consideraçðes baseadas em observaçठes feites com alunos e professores, - conclue que as falhas de leitura do professor sobre o texto do aluno se detêm na linguagem, esquecendo-se do trabalho que se faz com a mesma. Sugere que o professor pode levar o aluno à reescrita do texto através de "operaçōes linguísticas de adiçăo, de substituiçăo, de detalhamento, etc." (p. 53).

Maria Lúcia Z. Souza, evidenciando as dificuldades com o ensino da leitura na escola, incursiona por fatos que ocorrem nesta instituiçáo, relacionando-os com a linguagem, a alfabetizaçăo e a pouca possibilidade que se dá ao aluno de "interpretar, representar, ou captar o mundo pela palavra" (p. 75).

Ana Maria B. Garcez Yasuda, diante da constataçăo de que a escola tem formado "muitos alfabetizados nas letras e que poucos sabem efetivamente ler" (p. 77), faz consideraçסes sobre o uso do livro didático de português nas escolas, cuja "concepçāo de construçāo do conhecimento" está longe do ideal e/ou do desejado.

$\mathrm{Na}$ busca de soluçóes, alguns autores relatam experiências e pesquisas que servem de base para demonstrar as possibilidades de progresso no ensino da linguagem e da leitura. Deste modo, Raquel $S$. Fiad e Maria Laura T. Maryrink-Sabinson relatam $\theta$ exemplificam a experiência de reescrita de textos com alunos universitários, onde os mesmos foram "leitor e revisor de seus textos e dos seus colegas". A experiência mostrouse positiva, na medida em que as mudanças levaram a uma maior adequação ao tipo de texto exigido, provo-

1 - Docente do Departamento de Biblioteconomia da Universidade Estadual de Londrina, Calxa Postal 6001, Londrina, Parand, Brasil, CEP 86051-970, Mestranda do Curso de Pós-Graduação em Biblioteconomia da PUCCAMP. 
cando modificaçōes que visavam torná-lo mais claro ou adequado para a leitura.

Observamos que essa pode ser uma experiência para remediar as deficiências de escrita, que obviamente contribuirão para um avanço nas aptidōes de leitura. Entre as modificaçōes passiveis de ocorrer, Sonia Ignez G. Fernandez relata uma atividade de mediaçăo do professor, no trabalho de leitura com estudantes universitários e professores da rede municipal e estadual de ensino de São Paulo. Tendo por base teórica os estudos de Wolfgang Iser sobre "A interaçăo do texto com o leitor", a autora conclui e corrobora a argumentaçăo de Iser de que "a interação fracassa quando as projeçōes dos participantes nảo sofrem mudanças ou quando as projeçōes do leitor se impōem independentemente do texto" (p. 69).

Considerando a imensa critica que se faz ao baixo nivel e a pouca leitura do brasileiro, os textos mostram o entrelaçamento da linguagem, da escrita e da leitura. Apresenta instrumentos que possibilitam modificar esta realidade. As experiências relatadas deixam-nos um alento, carregado de pensamentos positivos, de que é possivel sair de um modelo opressor para um modelo libertador.

SOUZA, Solange de Cassia I. de1. Merenda escolar na complexidade do quadro institucional: a experiência do

Paraná. São Paulo, 1992. Dissertação (Mestre em Economia) - Pontificia Universidade Católica de São Paulo.

No Brasil, o processo de industrializaçáo prevalecente desde os anos 50 contribuiu para o agravamento das disparidades sociais, cuja base esta fundamentada na concentraçăo de renda e na manutençăo de grande parte da populaçăo à margem deste processo. A repercussáo social do desenvolvimento económico, isto $E$, a distribuiçăo dos seus beneficios foram extremamente desiguais para o conjunto da sociedade, revelando a almentação e a nutriçáo como algumas das suas mais expressivas caréncias básicas. O Programa Nacional de Alimentaçăo Escolar apresenta-se como parte da solução de curto prazo para este problema; sua perspectiva modificou-se com a oportunidade propiciada pelo perfodo de transiçáo poltico-institucional que conduziu à redeliniçáo do papel do Estado na sociedade e sua torma de expressáo federal, e de modo particular, com a Carta Constitucional de 1988 que vabrizou o municfpio e consagrou o direito da criança à alimentaçáo escolar. Neste contexto, o trabalho tem como objetivo o exame do percurso institucional da merenda escolar dentro da perspectiva descentralizadora dos anos 80. Parte dos aspectos mais gerais a respeito da pobreza, fome e desnutriçăo no Brasil, passa pelos programas de alimentaçăo e nutriçăo implementados no pals e se fixa na questáo da merenda escolar. Detém-se no estudo da experiéncia da descentralizaçáo da alimentaçáo dos escolares no estado do Paraná, percebendo-se diferentes altemativas para o tratamento da questăo. Por fim, a dissertaçấ enfatiza a necessidade de mudanças nas articulaçós institucionais orientadas por um planejamento que reconcilie as dimensbés técnica e social, promovendo a prática de um novo relacionamento entre o Estado e a sociedade civil. 1. - Docenta do Departamento de Economia/CESA - Universidade Estadual de Londrina, Caixa Postal 6001, Londrina - Pr, Brasil, CEP
$86051-970$ 